\title{
A new look into an old problem: keratins as tools to investigate determination, morphogenesis, and differentiation in skin
}

\author{
Raphael Kopan and Elaine Fuchs \\ Departments of Molecular Genetics and Cell Biology and Biochemistry and Molecular Biology, The University of Chicago, \\ Chicago, Illinois 60637 USA
}

\begin{abstract}
We have investigated keratin and keratin mRNA expression during (1) differentiation of stem cells into epidermis and hair follicles and (2) morphogenesis of follicles. Our results indicate that a type I keratin K14 is expressed early in embryonal basal cells. Subsequently, its expression is elevated in the basal layer of developing epidermis but suppressed in developing matrix cells. This difference represents an early and major biochemical distinction between the two diverging cell types. Moreover, because expression of this keratin is not readily influenced by extracellular regulators or cell culture, it suggests a well-defined and narrow window of development during which an irreversible divergence in basal and matrix cells may take place. In contrast to $\mathrm{K14}$, which is expressed very early in development and coincident with basal epidermal differentiation, a hairspecific type I keratin and its mRNA is expressed late in hair matrix development and well after follicle morphogenesis. Besides providing an additional developmental difference between epidermal and hair matrix cells, the hair-specific keratins provide the first demonstration that keratin expression may be a consequence rather than a cause of cell organization and differentiation.
\end{abstract}

[Key Words: Hair-specific keratins; keratin mRNA expression; hair follicle morphogenesis]

Received September 28, 1988; revised version accepted November 22, 1988.

Encoded by a large multigene family, keratins constitute a group of $>20$ proteins $(40 \mathrm{~K}-70 \mathrm{~K})$, which form 8 -nm filaments in the cytoplasm of most, if not all, epithelial cells (for review, see Moll et al. 1982a,b; Sun et al. 1984; Steinert et al. 1985; Fuchs et al. 1987). These proteins can be subdivided into two distinct groups, type I and type II, depending upon their sequences (Hanukoglu and Fuchs 1982, 1983; Crewther et al. 1983; Steinert et al. 1983, 1984; Jorcano et al. 1984a,b): Type I keratins are generally small $(40 \mathrm{~K}-56.5 \mathrm{~K})$ and acidic (pKi, 4.5-5.5), whereas type II keratins are larger $(53 \mathrm{~K}-67 \mathrm{~K})$ and more basic (pKi, 5.5-7.5). Pairs of type I and type II keratins are expressed in a tissue-specific, differentiation-specific, and developmental-specific fashion (Eichner et al. 1984; Sun et al. 1984), suggesting that the pattern of expression of keratins might be tailored to suit the particular structural requirements of different epithelial cells.

In epithelial cells of skin, keratins are the major differentiation-specific proteins. As such, they are useful biochemical tools to probe the complex development of epidermis and its appendages from a single layer of embryonic ectodermal cells. This early embryonic layer has a morphology similar to simple epithelial tissues, and its cells express simple epithelial keratins (Jackson et al. 1981; Moll et al. 1982a,b). Very early in development, a two-layered epidermis forms. The inner layer is the embryonic basal layer, which ultimately gives rise to epidermis and its appendages. The outer, periderm layer still displays characteristics of simple epithelial cells. In subsequent stages of development, this layer is shed from the skin surface. Analysis of keratins extracted from fetal human skin at the two-layer stage has revealed the presence of $\mathrm{K} 5$ which, with its partner K14 (expressed shortly thereafter), forms the keratin pair expressed in the adult basal epidermal layer (Moll et al. 1982b; Nelson and Sun 1983). In all mammals, the first signs of epidermal differentiation appear at the time when the epidermis stratifies to form a middle (third) layer (Pinkus 1910; Davidson and Hardy 1952; Montagna and Parakkal 1974). Keratins K1, K2, K10, and K11 are made subsequently, and their levels continue to increase as the epidermis stratifies further and undergoes terminal differentiation (Jackson et al. 1981; BanksSchlegel 1982; Moll et al. 1982a,b; Dale et al. 1985). Epidermal differentiation seems to be dependent upon some factor(s) provided by the dermis (for review, see Billingham and Silvers 1968).

At approximately the same time that a three-layered epidermis forms, primary hair germs begin to develop. These appear as invaginations of the embryonic basal layer, and they always occur directly above aggregations of specialized mesenchymal cells, the anlagen of dermal papillae (Davidson and Hardy 1952; Wessels and Roessner 1965; Breathnach and Smith 1968; Meyer and Gorgen 1986). The dermal papilla cells seem to be essential in stimulating the development of primary hair 
germs, which ultimately differentiate into hair follicles, sebaceous glands, and apocrine glands (Jacobson 1966; Kollar 1970; Oliver 1970). However, it is still a matter of some controversy whether a narrow developmental window of responsiveness exists, during which time the differentiative program of a basal cell can be influenced by dermal papillae, or whether the responsive potential is retained by epidermal cells of all ages (Davidson and Hardy 1952; Billingham and Silvers 1968; Moscona and Garber 1968; Koller 1970; Oliver 1970; Dhouailly 1977; Jahoda et al. 1984; Pisansarakit and Moore 1986).

The structure of the hair follicle is far more complex than that of the epidermis (Fig. 1). Although all follicle cells are derived from the embryonic ectoderm, there are at least six to eight distinct cell types. With the possible exception of matrix cells, all of the cell types seem to

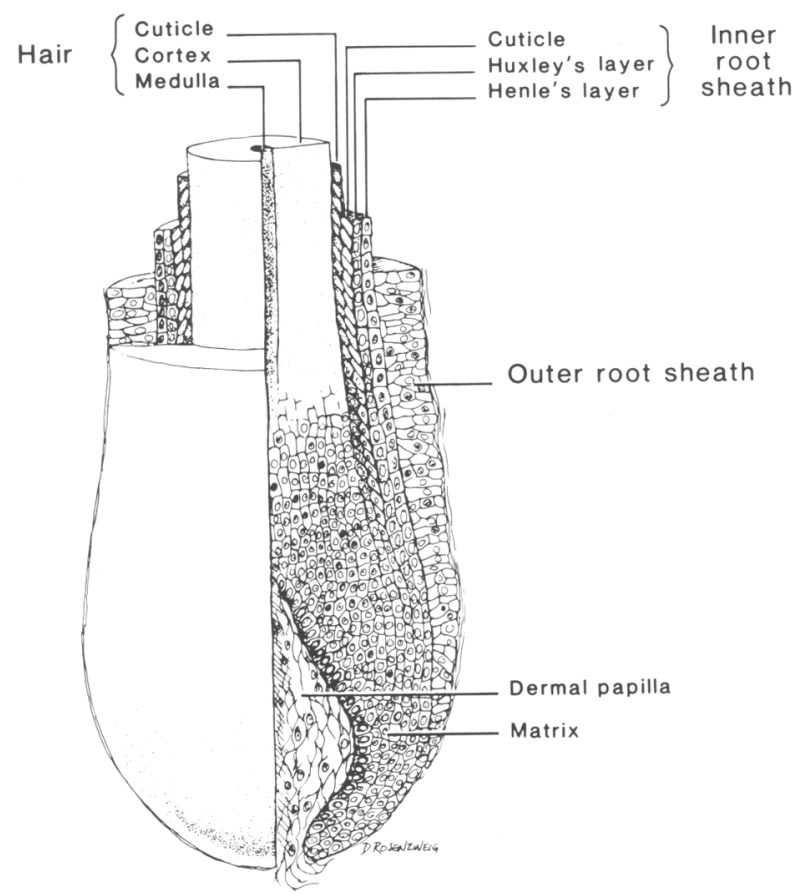

Figure 1. Differentiated cell types within the adult hair follicle. The hair follicle forms as a bulb around the specialized mesenchymal cells, i.e., dermal papilla. The relatively undifferentiated matrix cells are derived from the embryonic basal layer of developing rat skin and give rise to concentric rings of differentiated cells types, including the medulla, the cortex, and the cuticle of the cortex. The hair is surrounded by two root sheaths. The inner root sheath is composed of three cell types: the inner root sheath cuticle, and Huxley's and Henle's layers; the outer root sheath is composed of multiple layers of a single cell type. At the base of the dermal papilla, the inner root sheath cells are active mitotically and give rise to cells that migrate upward in single cell layers of distinct differentiative pathways. The outer root sheath cells do not come into direct contact with the dermal papilla. They are contiguous with the basal epidermal layer, but they are distinct and self-propagating. Although the dermal papillae seem to be important in controlling the differentiative program of the hair follicle, the precise pathways leading to the development of distinct follicle cell types remain obscure. contain 8-nm keratin filaments, and these are often composed of specialized keratins not found in epidermis or in other appendages of the skin. One set of hair-specific keratins is present in the medulla, cortex, and cortex cuticle (Marshall and Gillespie 1977; Crewther et al. 1983; French and Hewish 1986; Heid et al. 1986; Ito et al. 1986; Lynch et al. 1986). Another set of keratinlike proteins in the inner root sheath has not yet been fully characterized but seems to be distinct from all previously reported keratins (Steinert et al. 1971; Lynch et al. 1986; Stark et al. 1987). In contrast, the outer root sheath cells do not make hair-specific keratins, but rather express $\mathrm{K} 6, \mathrm{~K} 16$, and $\mathrm{K} 17$, characteristic of hyperproliferating epidermal cells, and also K5 and K14 (Moll et al. 1982a; Weiss et al. 1984; French and Hewish 1986; Stark et al. 1987; Stoler et al. 1988). Heid et al. (1988a,b) have reported that inner root sheath and matrix cells also express $\mathrm{K} 14$, but the antibodies used to make this claim are not monospecific, and some confusion exists over the interpretation of the data as it is presented (cf. Nagle et al. 1986; Heid et al. 1988a,b). On the contrary, most studies have not detected epidermal keratins in cells of the inner follicle (Moll et al. 1982a; Heid et al. 1986; Lynch et al. 1986). However, in situ hybridization with epidermal-specific cRNA probes have not yet been used to resolve the issue.

Although the discovery of differences in keratin patterns has helped to clarify some interrelations among follicle cells, a number of important questions remain unanswered, including: (1) What are the biochemical characteristics of the stem cells that give rise to both epidermis and hair follicles? (2) Are these two pathways of development and differentiation irreversible ones? (3) Do hair-specific keratins play a role in morphogenesis of hair follicles? To begin to unravel the answers to these questions, we have utilized monospecific anti-keratin antisera and keratin cRNA probes and have examined in more detail the changes in keratin protein and mRNA expression during fetal rat epidermis and hair follicle development. Our results have revealed new insights into our understanding of epidermal and hair development and the extent to which morphological differentiation and keratin expression are linked in these programs.

\section{Results}

The development of epidermis and hair follicles in fetal rat skin

To examine epidermal and hair follicle development, we used hematoxylin and eosin to stain sections $(5 \mu \mathrm{m})$ of back skin from rat embryos at various developmental stages (Fig. 2). As is typical for all mammals, development proceeded in a head-to-tail fashion, and for early embryonic rat skin (15G-16G), back development lagged behind head development by $\sim 1$ day (for differences between the back and head, respectively, at 16 days gestation see Fig. 2, $16 \mathrm{G}^{\mathrm{B}}$ and $\left.16 \mathrm{G}^{\mathrm{H}}\right)$. Until 15 days of gestation, the developing back epidermis appeared as a single-layered epithelium. By 16 days of gestation $\left(16 G^{\mathrm{B}}\right)$, the back epithelium was two layered $\left(\mathrm{Pr}_{;} \mathrm{EBL}\right)$. 

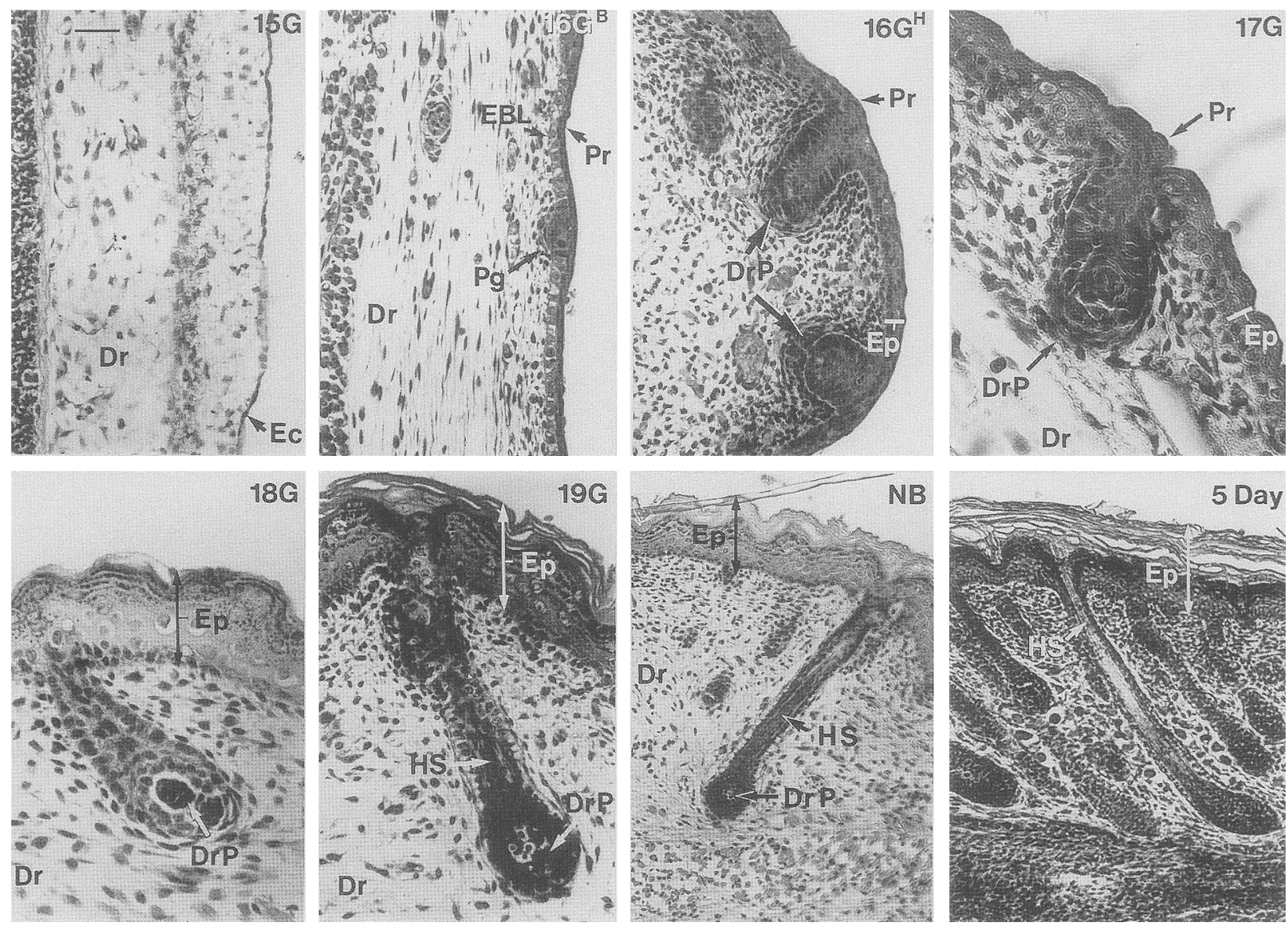

Figure 2. Morphological stages of development in embryonic rat skin. Rat embryos at various stages of development were fixed in Carnoy's solution, embedded in paraffin, and sectioned $(5 \mu \mathrm{m})$. Sections were stained with hematoxylin and eosin. Sections shown are from embryos at 15-19 days of gestation (15G-19G, respectively), newborn (NB), and 5 days postbirth. All sections shown are from back skin, with the exception of $16 \mathrm{G}$, where both back skin $\left(16 \mathrm{G}^{\mathrm{B}}\right)$ and head skin $\left(16 \mathrm{G}^{\mathrm{H}}\right)$ samples are shown to illustrate the more advanced development of the head vibrissae (whiskers) region at early embryonic stages. (Dr) dermis; (Ec) embryonic ectoderm; $(\mathrm{Pg})$ primary hair germ, (EBL) embryonic basal layer, $(\mathrm{Pr})$ periderm, (Ep) epidermis, $(\mathrm{HS})$ hair shaft, (Drp) dermal papilla. Bar represents 30 $\mu \mathrm{m}$ for $15 \mathrm{G}, 16 \mathrm{G}^{\mathrm{B}}, 16 \mathrm{G}^{\mathrm{H}}$, and $19 \mathrm{G} ; 15 \mu \mathrm{m}$ for $17 \mathrm{G}$ and $18 \mathrm{G} ; 50 \mu \mathrm{m}$ for $\mathrm{NB}$ and 5 days postbirth.

Within a day, the epidermis stratified into a multilayered structure, aggregates of dermal papilla anlage cells were readily apparent, and primary hair germs had begun to elongate (17G). As the back epidermis continued to thicken, the first signs of stratum corneum formation were seen (18G-19G). Developing follicles engulfed their pockets of dermal papillae to form bulbarlike structures, and the hair canals of fetal hairs began to appear. Hairs continued to grow and broke the skin surface at $1-3$ days postbirth (see NB and 5 days postbirth). Although the epidermis had reached close to maximal thickness by 19 days of gestation, hair follicle density continued to progress until $\sim 2$ days postbirth; whereas average follicle size increased until $\sim 5$ days postbirth. Collectively, these morphological data are in general agreement with previous studies conducted on mice (Davidson and Hardy 1952), pigs (Meyer and Gorgen 1986), and humans (Pinkus 1910, 1958; Hashimoto 1970).

\section{Keratin patterns in fetal rat skin}

Keratin extractions and protein gel analyses previously have shown that both the embryonic ectoderm and periderm of human fetal skin express the simple epithelial keratins $\mathrm{K} 8, \mathrm{~K} 18$, and $\mathrm{K} 19$; and as the periderm disappears, expression of these proteins wanes (Jackson et al. 1981; Moll et al. 1982b; Dale et al. 1985). Because these keratins are relatively minor components of developing skin and because they are expressed prior to differentiation, we will not discuss them further.

When protein extracts enriched for keratins were isolated from embryonic rat skin and resolved by SDSpolyacrylamide gel electrophoresis, it was evident that a large increase in the level of proteins of $46 \mathrm{~K}-66 \mathrm{~K}$ occurred at 18 days of gestation (Fig. 3A). Immunoblot analyses with type-specific antisera (Fig. 3B, type I; Fig. $3 \mathrm{C}$, type II) and two-dimensional gel analyses with silver staining (Fig. 3D) revealed that this major increase in keratins was due to the appearance of $\mathrm{K} 1(66 \mathrm{~K}), \mathrm{K} 10$ 


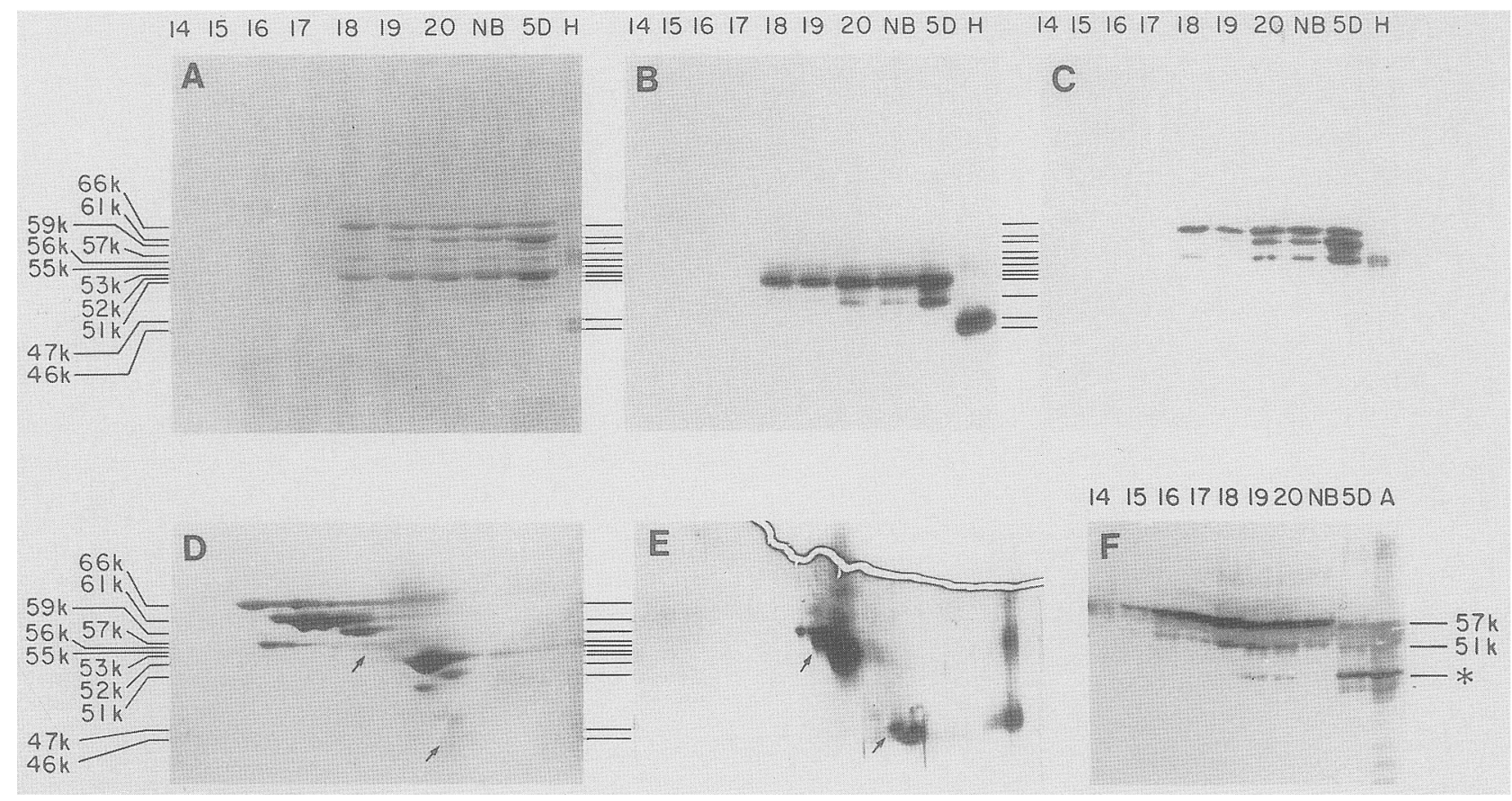

Figure 3. Protein and immunoblot analyses of the keratins from developing embryonic rat skin. Keratins were extracted from back skins of rat embryos at various developmental stages and of rats postbirth. Samples were resolved by either one-dimensional electrophoresis through $8.5 \%$ SDS-polyacrylamide gels $|A-C, F\rangle$ or two-dimensional electrophoresis with nonequilibrium pH gradient gel electrophoresis (O'Farrell et al. 1977) in the first dimension, and SDS-polyacrylamide gel electrophoresis in the second dimension (D; 5 days postbirth sample; $E$, adult hair sample $\mid$. Intermediate filament proteins were isolated either directly from tissues $(F)$ or following RNA extraction $(A-E$; see Experimental procedures $\mid$. Gels were either subjected to Coomassie Blue staining $|A|$, silver staining $(D, E)$, or immunoblot analysis as described in Experimental procedures $(B, C, F)$. For immunoblot analysis, the primary antiserum used was either largely preferential for type I epidermal and hair keratins $(B)$, type II epidermal and hair keratins $|C|$, or basal epidermal keratins $\langle F\rangle$. Lanes represent keratin samples from the back skin of embryos at 14-20 days of gestation, respectively (14-20); newborn rat $(\mathrm{NB})$; rat at 5 days postbirth $(5 \mathrm{D})$, adult $(\mathrm{A})$, a keratin sample extracted from adult rat hair clippings $(\mathrm{H})$. Although $\mathrm{H}$ contains pure hair keratins, these keratins were also readily detected in samples of total keratins extracted from adult skin. The isoelectric mobilities of the major type II $(\mathrm{Hb})$ and type I $(\mathrm{Ha})$ hair keratins can best be seen in $(E)$. In the 5 days postbirth sample $(D)$, with the exception of $\mathrm{Hbl}(59 \mathrm{~K})$ which was expressed at high levels, the hair-specific keratins were barely detectable (cf. arrows in $D$ and $E$ ) relative to epidermal keratins. Molecular masses of keratins were estimated using protein standards and are indicated on the diagrams. According to their isoelectric mobilities, their expression patterns, and immuno-cross-reactivities, these keratins are $\mathrm{Kl}$ (66K), $\mathrm{K} 2(61 \mathrm{~K}), \mathrm{K} 5(57 \mathrm{~K}), \mathrm{K} 6(56 \mathrm{~K}), \mathrm{K} 10 / \mathrm{K} 11(53 / 52 \mathrm{~K}), \mathrm{K} 14(51 \mathrm{~K})$, the hair-specific type II $(\mathrm{Hb})$ keratins $(59 \mathrm{~K} ; 56 / 55 \mathrm{~K})$, and the hair-specific type I (Ha) keratins (47/46K), according to the nomenclature of Moll et al. (1982b) and Heid et al. (1986). Notes: The asterisk (*) in F indicates the presence of a band detected with anti-keratin antiserum, which is not Ha based on the difference in their isoelectric points (data not shown). $(D)$ The spots at $\sim 50.5 \mathrm{~K}$ and $50 \mathrm{~K}$ are most likely keratins, but whether they represent $\mathrm{K} 16$ and $\mathrm{K} 17$, respectively, or whether they are early type I hair keratins analogous to the type II 59K keratin, was not determined.

$(53 \mathrm{~K})$, and $\mathrm{K} 11(52 \mathrm{~K})$. An anti-keratin antiserum preferentially recognizing basal epidermal keratins indicated that $\mathrm{K} 5(57 \mathrm{~K})$ and its partner $\mathrm{K} 14(51 \mathrm{~K})$ preceded the expression of terminal differentiation-specific keratins, and were already present by $15-16$ days (Fig. 3F, lanes 15 and 16). However, once stratification of the epidermis occurred, the basal keratins became overshadowed by the large amounts of $\mathrm{K} 1 / \mathrm{K} 2$ and $\mathrm{K} 10 / \mathrm{K} 11$ (e.g., see Fig. 3A). Collectively, these data are consistent with previous epidermal keratin analyses conducted on embryonic human skin (Moll et al. 1982a,b; Dale et al. 1985).

In addition to identifying epidermal keratins, our type-specific antisera also recognized rat hair keratins. Figure 3B shows that type I hair keratins $(46 \mathrm{~K}-47 \mathrm{~K}$ ) were readily detected in an extract of adult hair clippings (lane H) but not in prebirth or early postbirth skin samples (other lanes in Fig. 3B). Due to the near comi- gration of hair-specific and epidermal type II keratins, it was not possible to determine the timing of appearance of the type II hair keratins by one-dimensional gel analysis (Fig. 3C). However, two-dimensional gel analysis showed the characteristic and distinct isoelectric mobilities of both the type I and the type II hair-specific keratins (Fig. 3D,E; Heid et al. 1986; Lynch et al. 1986). The earliest detectable hair keratin seemed to be the rat equivalent of $\mathrm{Hbl}$, the largest $(59 \mathrm{~K})$ and most basic type II hair-specific keratin (Heid et al. 1986; Lynch et al. 1986). $\mathrm{Hbl}$ appeared as early as 20 days of gestation, but even at 5 days postbirth, its level was low relative to epidermal keratins (Fig. 3D). At these times, other hair keratins were barely detectable (see arrows in Fig. 3D). Interestingly, the expression of hair keratins did not begin to increase dramatically until after 5 days postbirth, at a time when follicle density and morphology 
were largely fixed. Furthermore, the rise in hair keratin production was due to the other type II and type I keratins, rather than $\mathrm{Hbl}$ (arrows in Fig. 3E). Whether some of these other hair keratins arise from post-translational processing of $\mathrm{Hbl}$ or whether they each represent distinct gene products was not determined.

\section{Localization of K14 during fetal skin development}

Because K5 and K14 seemed to appear concomitantly with the differentiation of the embryonic basal layer into epidermis and hair follicles, we wanted to determine whether both cell types expressed these proteins. For immunohistochemical studies, we used a polyclonal antisera made against a synthetic 15-mer peptide to the carboxy-terminal end of human K14 (Stoler et al. 1988). This antiserum is monospecific for both human (Stoler et al. 1988) and mouse K14 (R. Vassar and E. Fuchs, unpubl.). When skin sections from different stage rat embryos were stained with this antiserum, K14 expression was first detected in the innermost layer of the twolayered epidermis (Fig. 4A). No staining could be seen in the single-layered epidermis (not shown) or in the periderm layer of the two-layered epidermis (Pd, Fig. 4.4). Moreover, even though primary hair germ structures could be seen at the same time that K14 staining appeared in the basal epidermal layer, little or no anti-K14 staining was observed in these structures (Pg, Fig. 4A).
The absence of anti-K14 staining became even more evident as development of the hair follicle proceeded. By 17-18 days of gestation, many hair germ cells had already begun to differentiate into readily distinguishable prefollicle structures, and yet little or no K14 was detected (Fig. 4B). By 19-20 days of gestation, K14 expression increased in the basal epidermal layer, and some staining extended to the spinous layers; however, K14 still seemed to be low or absent in the growing follicle (Fig. 4C,D). At birth, K14 began to appear in hair follicles, but it was only seen in outer root sheath cells. This expression increased within the first few days postbirth and was clearly visible in most outer root sheaths of the adult rat (Fig. 4E). No K14 staining was seen in the matrix, cortex, cortex cuticle, or inner root sheath.

\section{Expression of K14 mRNA during rat skin development}

To determine whether the dramatic differences in antiK14 staining patterns of epidermal and hair follicle structures during development were due to differences in $\mathrm{K} 14$ expression or, alternatively, to differential masking of the carboxy-terminal sequence of K14, we conducted in situ hybridization using ${ }^{35} \mathrm{~S}$-labeled cRNAs specific for the coding and 3' noncoding portions of K14 mRNA. Similar to the anti-K14 staining pattern, K14 cRNA hybridization was seen at low, but detectable levels in the epidermis, as early as 17 days of gestation (Fig. 5A,B). As the epidermis began to stratify and un-

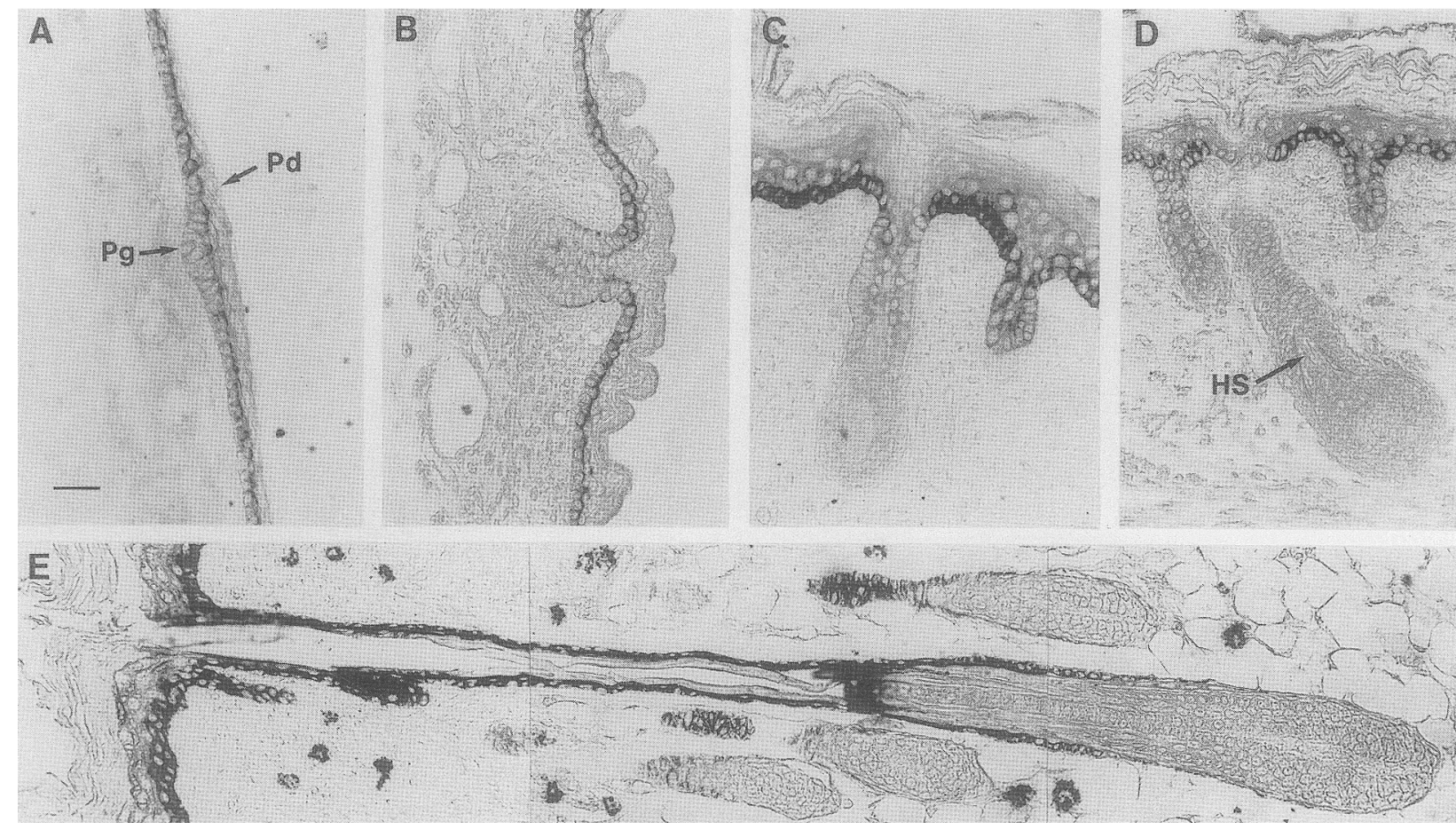

Figure 4. Immunohistochemical localization of $\mathrm{K} 14$ in developing rat skin. Back skins from embryos at 14-20 days of gestation, as well as from rats at $t=0,2,5,7,15$, and 30 days postbirth, and from adult rats, were fixed in $4 \%$ paraformaldehyde, embedded in paraffin, and sectioned $(5 \mu \mathrm{m})$. Sections were subjected to anti-K14 immunohistochemistry, as described in Experimental procedures. Sections shown were from embryos at 16 days of gestation $(A), 17$ days of gestation $(B), 19$ days of gestation $(C), 20$ days of gestation $(D)$, and adult $(E)$. Bar represents $30 \mu \mathrm{m}$. $(\mathrm{Pg})$ Primary hair germ; $(\mathrm{Pr})$ periderm; $(\mathrm{HS})$ hair shaft. 

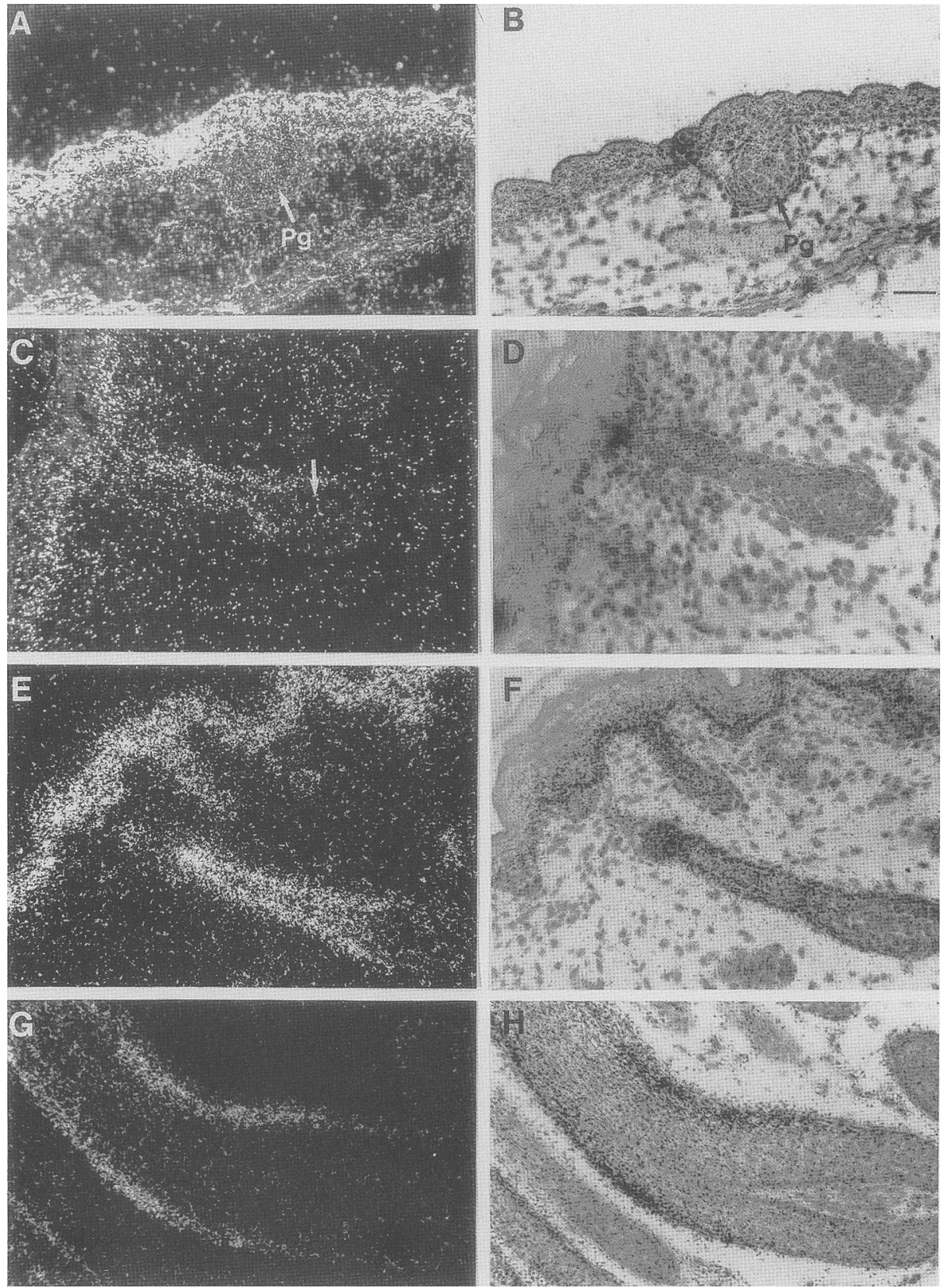

Figure 5. In situ hybridization of radiolabeled K14 cRNA probes to sections of developing rat skin. Back skins from embryos at 17-20 days of gestation, from rats at $t=0,2,5,7,9,15$, and 30 days postbirth, and from adult rats were fixed in 4\% paraformaldehyde, embedded in paraffin, and sectioned $(5 \mu \mathrm{m})$. Sections were subjected to in situ hybridizations using antisense K14 cRNAs labeled with ${ }^{35}$ S-labeled-UTP as probes, as described in Experimental procedures (Cox et al. 1984). Hybridized sections were dipped in photographic emulsion and exposed for 5 days $(A-D)$ or 3 days $(E-H)$ prior to developing. Sections were then stained with hematoxylin and eosin, and grains were visualized under both dark-field (left) and light-field (right) microscopy. Samples shown are from the back skin of: an embryo at 17 days of gestation $(A, B)$, a newborn rat $(C, D)$, a rat at 2 days postbirth $(E$, $F)$, and a hair follicle from a rat 5 days postbirth $(G, H)$. Note the absence of $\mathrm{K} 14 \mathrm{mRNAs}$ in the primary hair germs (arrows in $A, B$ ), in the developing follicle cells immediately adjacent to the dermal papillae (arrow in $C$ ), and in the matrix and bulbar regions of the postbirth follicles $(E-H)$. Also note the presence of K14 mRNA in the outer root sheath cells of the newborn, 2- and 5-day-old rats $(C-H)$. Bar indicates $30 \mu \mathrm{m}$.

dergo differentiation, increased K14 mRNA levels were seen, and it became apparent that K14 mRNA expression was down-regulated in the suprabasal, terminally differentiating layers (e.g., see newborn, Fig. 5C,D). This down regulation was noted previously for adult human epidermis (Tyner and Fuchs 1986; Stoler et al. 1988).
In contrast to epidermis, cells of primary hair germs (arrows, Fig. 5A,B), matrix (Fig. 5C,D, arrow in C), and inner root sheath (Fig. $5 \mathrm{C}-\mathrm{H}$ ) showed no evidence of K14 mRNA expression. However at birth and increasing thereafter, K14 mRNAs were seen in outer root sheath cells (best seen in Fig. 5G-H). Hence, even though outer 
root sheath cells are contiguous with the basal layer of the epidermis, they undergo a significant period in development where little or no K14 protein or mRNA expression takes place. Moreover, in all cases, K14 mRNA expression paralleled K14 protein expression and demonstrated conclusively that changes in $\mathrm{K} 14$ synthesis occurred at the time when programs of epidermal and hair follicle differentiation were diverging.

\section{Detection of hair-specific keratin $m R N A$ s by Northern blot analysis}

Our initial protein analyses suggested that appearance of hair-specific keratins may trail behind morphogenesis in the hair follicle (see Fig. 2). To determine whether this finding is reflected at the level of the mRNA, we first isolated poly $(\mathrm{A})^{+}$mRNAs from skins of rat embryos at various developmental stages and conducted Northern blot analyses (Fig. 6). To verify that the isolated mRNAs were intact, we first probed the blot with a ${ }^{32} \mathrm{P}$-labeled cDNA specific for the coding portion of $\mathrm{K} 5 \mathrm{mRNA}$ (Lersch and Fuchs 1988). This type II probe was chosen over the type I K14 mRNA probe so that the hybridizing RNA (2.1 kb; Lersch and Fuchs 1988) would not comigrate with the hybridizing RNA expected from the use of

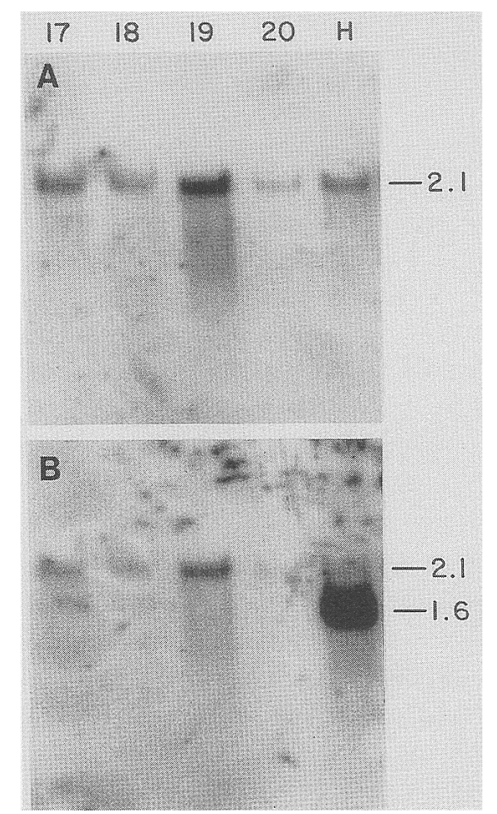

Figure 6. Northern blot analyses of basal epidermal and hairspecific RNAs from the back skin of developing rat embryos. Poly $(\mathrm{A})^{+}$RNAs from the back skins of rat embryos at 17-20 days of gestation (lanes 17-20, respectively) and from adult hair follicles (lanes $H$ ) were isolated and resolved by formaldehydeagarose gel electrophoresis as described by Thomas (1980). After transferring to nitrocellulose paper by blotting, the resolved mRNAs were first hybridized with radiolabeled singlestranded cDNA probes specific for K5 mRNA $|A|$, and then hybridized with a corresponding probe for hair-specific type I mRNAs $(B)$. Sizes of hybridizing mRNAs were estimated by migration of rRNA markers and are given at right in kilobases. a type I hair-specific keratin mRNA probe in the subsequent hybridization. Beginning at day 17 of gestation and after, K5 mRNAs were readily detected (Fig. 6A, lanes 17-20). As expected, K5 mRNA was also detected in RNA samples of adult hair follicles that contained outer root sheath cells (Fig. $6 \mathrm{H}$ ). Hence, as judged from our Northern blot analyses, the expression of $\mathrm{K} 5 \mathrm{mRNA}$ paralleled the pattern of appearance of $\mathrm{K} 14 / \mathrm{K} 5$ proteins and of K14 mRNA in developing rat embryos. Moreover, the detection of $\mathrm{K} 5$ mRNA verified the integrity of all mRNA samples.

To determine whether hair-specific keratin mRNAs were produced in significant quantities prior to birth, we probed the same blot with a ${ }^{32}$ P-labeled cDNA specific for a type I wool keratin mRNA (kindly provided by Dr. Kevin Ward). Figure 6B shows clearly that a new and strongly hybridizing band $(1.6 \mathrm{~kb})$ appeared in the sample from adult hair follicles (Fig. 6H), but not in any of the samples of skin from 17 to 20 days of gestation (lanes 17-20). This band corresponds to the predicted molecular size of the type I hair-specific keratin mRNAs (Dowling et al. 1986). Collectively, our immunoblot and Northern blot analyses suggest that the major appearance of hair-specific keratins and their mRNAs occurs after embryogenesis in the rat.

\section{Localization of the hair-specific mRNAs during fetal rat skin development}

If hair-specific keratin mRNAs were expressed in only a few cells of developing rat skin, it might be difficult to detect them by Northern blot analyses of total poly $(\mathrm{A})^{+}$ rat skin RNAs. To examine more precisely the expression of these mRNAs, we conducted in situ hybridization of embryo tissue sections (Fig. 7). No hair-specific keratin mRNAs were detected in any of the samples of fetal rat skin (see, e.g., Fig. 7A,B, 16 days of gestation; and Fig. $7 C, D, 19$ days of gestation). This was true even for follicles with evidence of fetal hair formation (e.g., Fig. $7 \mathrm{C}, \mathrm{D}$ ). At birth, some hybridization was detected, but it was generally low and was only found in a few follicles (see, i.e., Fig. 7E,F). By 2 days postbirth a few more follicles showed hybridization, but the levels of type I hair-specific keratin mRNAs were still low (Fig. $7 \mathrm{G}, \mathrm{H})$. However, by 5 days postbirth, these levels were elevated markedly (Fig. 7I,J).

A closer inspection of 5 days postbirth skin sections revealed a highly active and discrete region of cortex cells where most hair-specific cRNA hybridization was seen (Fig. 8A,B). Interestingly, these mRNAs were absent not only in matrix cells, but also in the single layer of cells surrounding the dermal papilla (Fig. 8C,D). Just above this layer, however, abundant hybridization was detected. No type I hair-specific keratin mRNAs were detected in any of the cells of the medulla or cuticle or in the inner and outer root sheaths (see also Fig. 9C,D).

In contrast to the localization of hair-specific keratin mRNAs, previous immunostaining analyses detected hair-specific keratins approximately two to four cell layers removed from the dermal papilla (French and Hewish 1986; Heid et al. 1986; Lynch et al. 1986). In addi- 

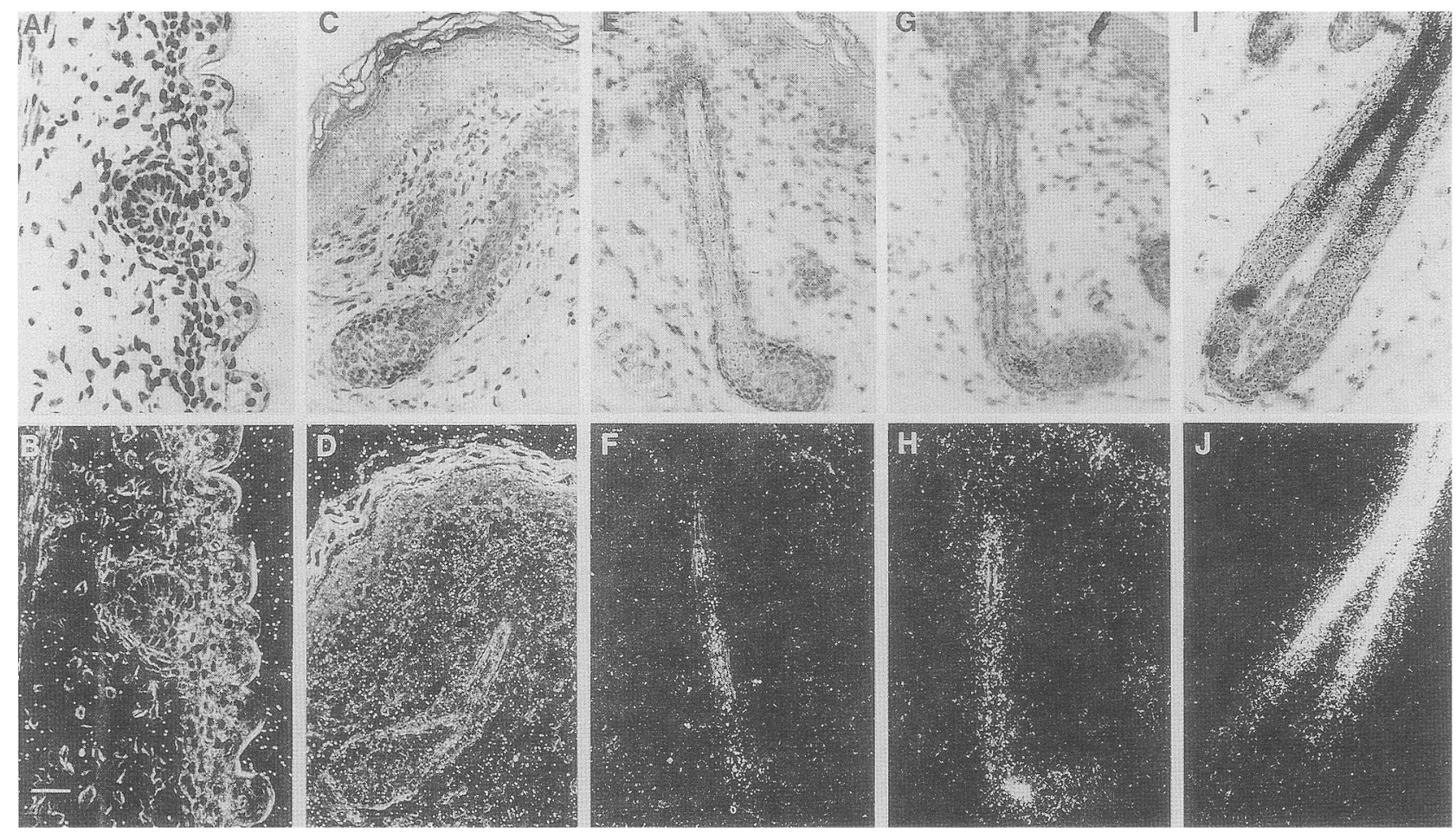

Figure 7. In situ hybridizations of radiolabeled hair-specific type I keratin cRNAs to sections of developing rat skin. Back skins from embryos at 16-20 days of gestation, from rats at $t=0,2,5,7,9,15$, and 30 days postbirth, and from adult rats were fixed in $4 \%$ paraformaldehyde, embedded in paraffin, and sectioned $(5 \mu \mathrm{m})$. Sections were subjected to in situ hybridization using antisense cRNA labeled with ${ }^{35} \mathrm{~S}$-labeled UTP specific for the hair-specific type I keratin mRNAs (Cox et al. 1984). Control hybridizations were also conducted using radiolabeled RNA corresponding to the sense strand of the type I keratin mRNA. After hybridization, sections were dipped in photographic emulsion and exposed for 5 days $(A-F)$ or 3 days $(G-/)$ prior to developing. Sections were then stained with hematoxylin and eosin, and grains were visualized by both light and dark-field microscopy. As expected, control hybridizations showed only background level grains (not shown). Skin samples shown are from 16-day-old gestation embryos $\{A, B\rangle, 19$-day-old gestation embryos $\langle C, D\}$, newborn rat $(E, F)$, rat at 2 days after birth $(G, H)$, and rat at 5 days after birth $(I, J)$. $(B)$ Bar represents $30 \mu \mathrm{m}$. Note the presence of light-scattering structures, but no radiolabeled grains, in the epidermis $(B, D)$.

tion, hair-specific proteins were seen in all upper cells of the cortex, cortex cuticle, and medulla. Because medulla cells contain hair-specific keratins, but not their corresponding mRNAs, it seems likely that they are derived from cortex cells through additional levels of differentiation. Moreover, similar to K5/K14, hair-specific keratins must be highly stable and persist after their mRNA synthesis has been downregulated.

\section{Developmental changes in the percentage of follicles expressing hair-specific keratin $m R N A s$}

When in situ hybridizations from 2- and 5-day postbirth skin samples were examined at low magnification, it became clear that marked differences existed in the overall numbers of follicles expressing hair-specific, but not epidermal-specific, keratin mRNAs (Fig. 9). Hence, only $\sim 15 \%$ of the 2 -day-old follicles showed hybridization with the hair-specific probe (Fig. 9A,B), whereas $>75 \%$ of the 5-day-old follicles showed such hybridization (Fig. $9 \mathrm{C}, \mathrm{D})$. These differences were not seen in K14 cRNA hybridizations (Fig. 9E-H). By 2 days postbirth, $100 \%$ of the follicles showed K14 cRNA hybridization over the outer root sheath cells (Fig. 9E, F). Between 2 and 5 days postbirth, the follicles lengthened considerably, but the levels of K14 mRNAs remained relatively unchanged.

\section{Discussion}

Does elevated expression of $K 14$ indicate a narrowing of pluripotency in epidermal cells?

Although K14 is expressed in embryonic epidermal cells as early as the two-layer stage in development, the choice between epidermal and hair follicle programs of differentiation seems to be made at a stage where K14 expression is extremely low. Elevated expression of K14 occurs in those cells that subsequently become basal epidermal cells, whereas maintenance of this low level of $\mathrm{K} 14$, or perhaps even downregulation of K14 expression, takes place in those cells that begin to form the primary hair germs and become destined to hair follicle differentiation.

The suppression of $\mathrm{K} 14$ seems to occur in those embryonic basal cells that come into close or direct contact with dermal papilla cells. It could be that a critical factor in determining $\mathrm{K} 14$ expression is the length of time that these cells come into direct contact with dermal pa- 
pillae. Thus, the matrix and innermost (most mitotically active) cells of the inner root sheath remain in direct contact with dermal papillae and show little or no evidence of K14 expression throughout development. In contrast, outer root sheath cells express $\mathrm{K} 14$ and arise late in development either from (1) a downward extension of epidermal cells that were never in contact with dermal papillae or (2) a population of hair follicle cells that have lost contact with dermal papillae.

It is well-established that dermal papillae provide an as yet unidentified inductive signal in hair follicle formation during both development and hair cycling (Davidson and Hardy 1952; Cohen 1961; Oliver 1966a,b, 1970; Kollar 1970; Dhouailly 1977; Pisansarakit and Moore 1986). However, there is still controversy over whether matrix cells are the only adult epithelial cells capable of responding to papillae or whether papillae have the inductive power to convert an adult epithelial cell into a matrix cell. Tissue recombination studies by Kollar (1970) and Pisansarakit and Moore (1986) have suggested that although adult dermal papillae seem to be proficient at inducing hair follicle formation in embryonic epidermis, the epidermal response may decline with age. Similarly, in vitro tissue disaggregation studies have demonstrated that suspensions of embryonic skin cells at early, but not late, stages of development can reaggregate to form feather (chick skin) or follicle (mouse skin) (Moscona and Garber 1968). Older skin cells not only failed to form follicles, but they also inhibited the ability of the younger ones to do so. These agedependent differences in the behavior of the embryonic epidermal component appeared to be even more important than species-related differences. Chimeric feather follicles were produced from aggregates of mouse and chick skin providing that the skins were taken from early stage embryos (Moscona and Garber 1968).

In striking contrast to these in vitro studies suggesting a restricted period of pluripotency for embryonic basal cells, Oliver and co-workers have claimed that dermal papillae are capable of inducing de novo hair follicle formation in adult epidermal cells. Their studies involved combining cells from purified rat vibrissae papillae with cells of rat epidermis from various body locations, including ear, oral mucosa, and scrotum (Oliver 1970). These epidermal/dermal reconstructions were then implanted beneath the epidermis of an adult rat ear. While follicle structures clearly formed, it was not demonstrated that these were bona fide hair follicles: only a few showed hair-like structures, and at the time, it was not possible to determine whether they contained the full complement of differentiated cell types expressing hair-specific keratins. Moreover, if epithelial-papilla cell recognition and migration did take place in vivo, then it seems equally plausible that nearby endogenous matrix cells (perhaps from follicles disrupted in the course of grafting/ may have been stimulated to migrate to the epidermal-papilla implants, but not to papilla implants alone. Since Dhouailly (1977) and Ibrahim and Wright (1982) have shown that dermal papillae are important in determining the nature of the developing follicle regardless of the origin of the epithelial component,
Oliver's finding that the resulting follicles were vibrissa-like does not reveal whether the epithelial component came from the donor or the host. Clearly, future investigations using donor and host mice harboring different identifiable genetic markers will be needed to clarify the question of pluripotency of epidermal cells. Such animals could be generated using transgenic mouse technology.

Although our results do not directly dismiss the notion that epidermal cells remain pluripotent throughout adult life, they argue against this suggestion. Our studies predict that biochemical conversion of epidermal cells to matrix cells should be accompanied by suppression of $\mathrm{K} 14$. However, in vivo, $\mathrm{K} 14$ (and K5) expression appears to be a faithful and permanent marker of stratified squamous epithelial basal cells (Doran et al. 1980; Nelson and Sun 1983). In addition, numerous in vitro studies on neonatal and adult epidermal cells have also shown that
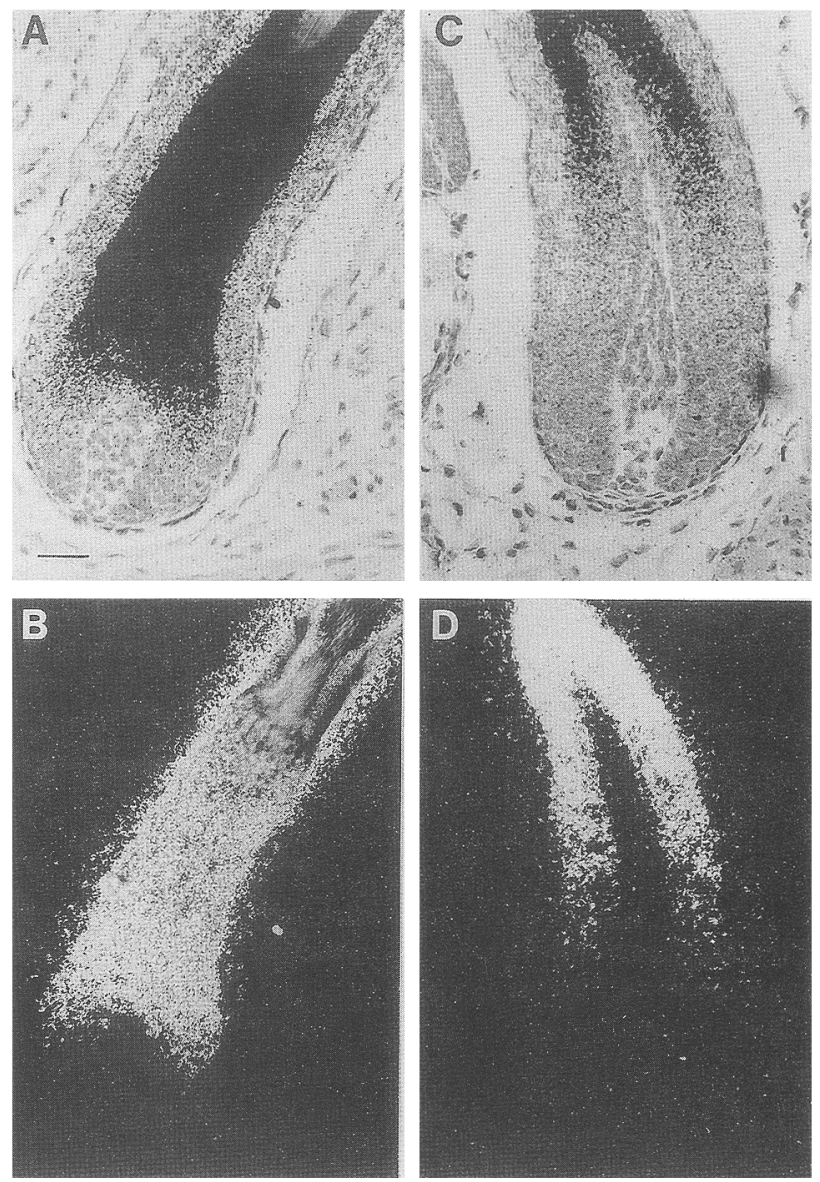

Figure 8. In situ hybridization of radiolabeled hair-specific type I keratin cRNAs to back skin of a rat at 5 days postbirth The back skin of a 5-day-old rat was fixed, embedded, sectioned $(5 \mu \mathrm{m})$, and then hybridized with a radiolabeled probe specific for hair-specific type I keratin mRNA (for details, see the legend to Fig. 7). Sections were dipped in photographic emulsion and exposed for 3 days prior to developing. Developed sections were stained with hematoxylin and eosin and then visualized by light-field $(A, C)$ and dark-field $(B, D)$ microscopy. $(A)$ Bar represents $30 \mu \mathrm{m}$. Note: $C$ and $D$ show a center section of a follicle; $A$ and $B$ show a more diagonal section displaying a greater proportion of cortical cells. 

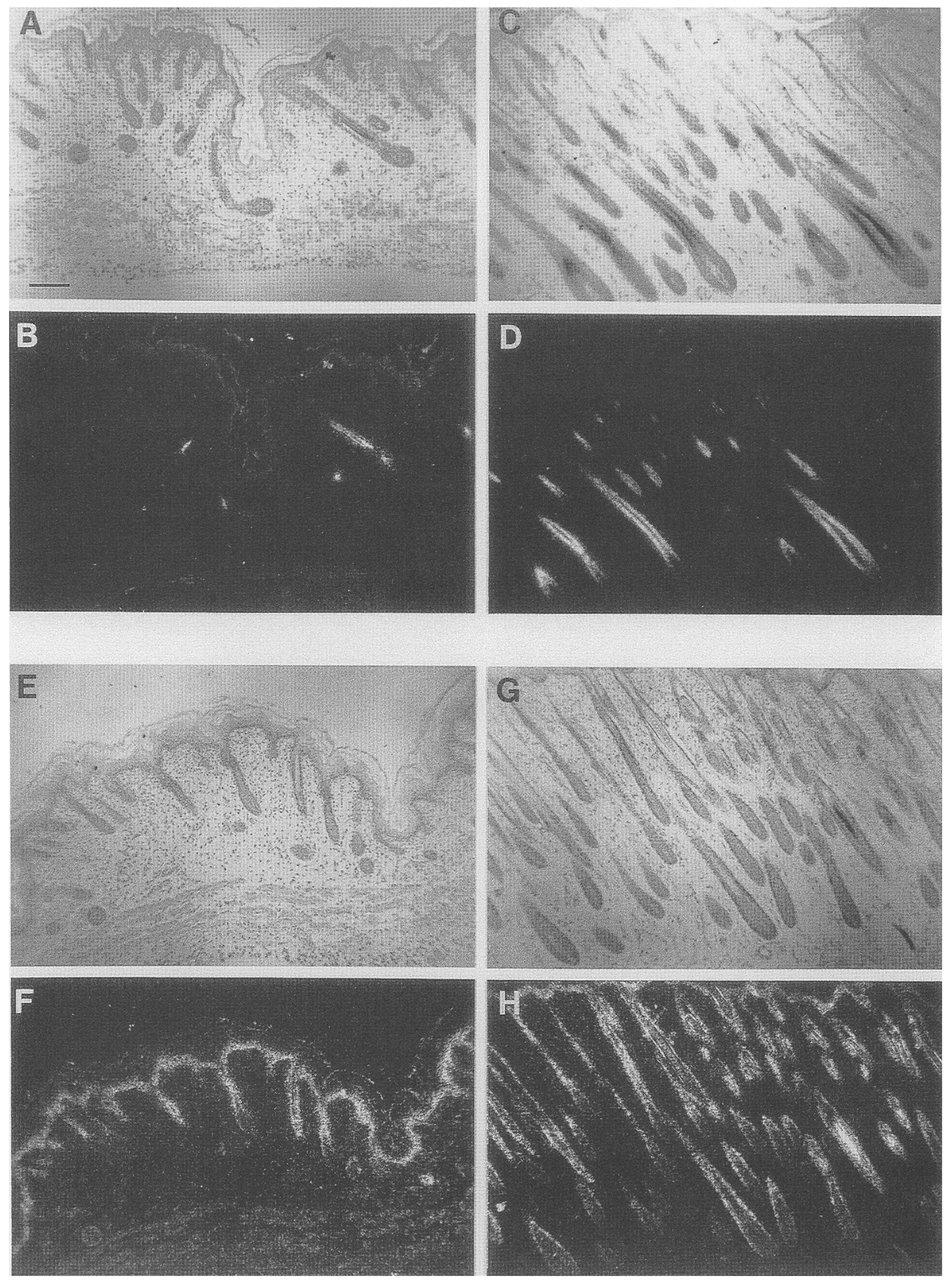

Figure 9. Changes in hair keratin mRNA expression in follicles occur between 2 and 5 days postbirth. Rat back skins were fixed and sectioned as described in the Experimental procedures. Sections were from either 2 days postbirth $(A, B, E, F)$ or 5 days postbirth $(C, D, G, H)$. Sections were hybridized with cRNA probes labeled with ${ }^{35}$ S-labeled UTP specific for either hair-specific type I mRNA $(A-D)$ or K14 mRNA $(E-H)$. Following hybridizations, sections were dipped in photographic emulsion and exposed for 3 days prior to developing. Fields are shown in both light-field and dark-field illumination. The epidermal thickness and the density of hair follicles was approximately the same for both 2- and 5-day samples. (A) Bar represents $120 \mu \mathrm{m}$. Note: Most fields of the 2 day postbirth skin sections hybridized with hair-specific cRNAs were negative. The field shown was maximal for hybridization and still illustrates the marked differences in hair-specific keratin mRNA expression in follicles from 2- and 5-day-old rats.

$\mathrm{K} 5 / \mathrm{K} 14$ is one of the few pairs of keratins whose expression is not dramatically influenced by extracellular regulators of epithelia such as epidermal growth factor (EGF), fibroblast feeder layers, cAMP-inducing agents, vitamin A, calcium, and transforming growth factor- $\beta$ (Rheinwald and Green 1975; Sun and Green 1978; Fuchs and Green 1980,1981; Hennings et al. 1980; Watt et al.
1984; Kopan et al. 1987). Moreover, we have tested the influence of cultured adult dermal papillae cells [prepared from rat vibrissae, according to the method of Oliver (1970)] on K5/K14 expression in cultured human epidermal cells, and we could not demonstrate an effect on $\mathrm{K} 5 / \mathrm{K} 14$ expression, nor did we detect hair-specific keratin induction (R. Kopan and E. Fuchs, unpubl.). 
Not only have efforts to convert epidermal cells into matrix cells been largely unsuccessful, but it also seems that adult matrix cells cannot be readily converted into epidermal cells. Despite numerous attempts, adult matrix cells do not seem to grow well when cultured in vitro using a variety of methods suitable for epidermal cell culture, and even organ culture studies have met with only very limited success (Davidson and Hardy 1952; Hewish and Marshall 1982; Rogers et al. 1987). Hence, there appear to be major biochemical differences between these two cell types, and these differences are maintained even when prominent changes are introduced into their environment.

Collectively, these data suggest that neither epidermal cells nor matrix cells can be interconverted once their determination from embryonic basal cells has occurred. The abundant expression of $\mathrm{K} 5 / \mathrm{K} 14$ may signify a largely irreversible determination of embryonic basal cells to basal epidermal cells. A model consistent with our findings is illustrated in Figure 10.

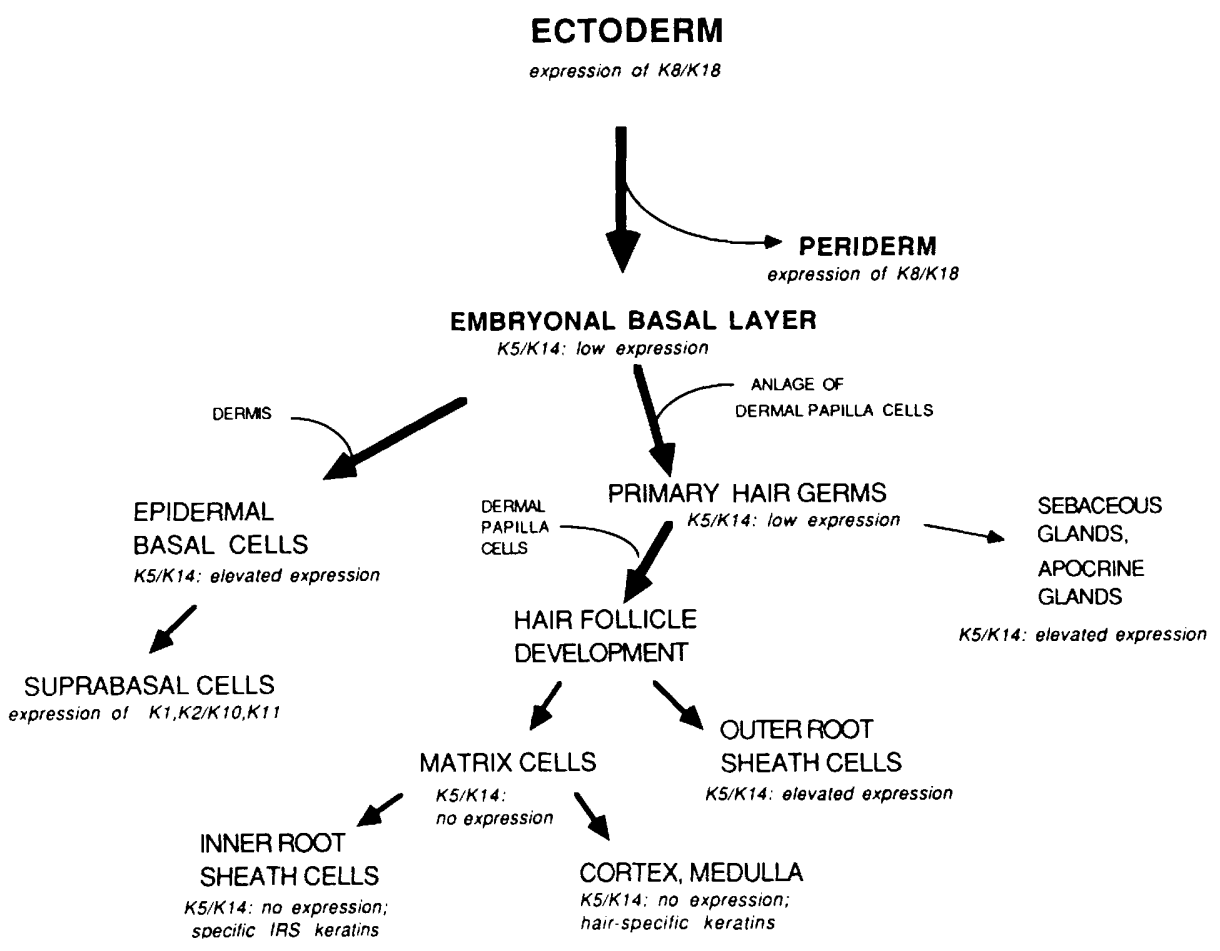

Figure 10. Model for determination and differentiation of epidermis and hair follicles based on patterns of keratin expression. Although it is based primarily on expression data for type I keratins, the model includes the appropriate type II keratin partners, as previous studies have indicated that keratins are coexpressed as specific type I-type II pairs (Nelson and Sun 1983; Sun et al. 1984) In the earliest stages of epithelial development in skin, a single-layered embryonic ectoderm, expressing simple epithelial keratins, gives rise to an embryonic basal layer expressing low levels of K14/K5. Two distinct programs of differentiation evolve from these cells: (1) a pathway of epidermal differentiation, marked by increased levels of K14/K5 in developing basal cells, and (2) a pathway of hair follicle differentiation, marked by suppression of $\mathrm{K} 14$ in developing matrix cells. The stimulus leading to epidermal differentiation seems to come from a nonspecialized dermal component of mesenchymal cells (see Billingham and Silvers 1968). The stimulus leading to hair follicle differentiation seems to come from a specialized dermal component, namely the anlagen of dermal papillae (see Cohen 1961; Kollar 1970; Oliver 1970). As hair follicle development proceeds, apocrine and sebaceous glands begin to develop, and their origin is generally assumed to be from the same cells that ultimately give rise to hair follicles. The difference in K14/K5 levels of hair matrix cells and basal epidermal cells denotes a distinct biochemical difference between these two cell types. Although the molecular nature of the divergence remains to be elucidated, it may be that during the course of development, the length of exposure of embryonic basal cells to dermal papillae influences the level of expression of $\mathrm{K} 14 / \mathrm{K} 15$. Hence, basal epidermal cells with no exposure to dermal papillae and outer root sheath cells with limited (if any) exposure to dermal papillae, show prominent levels of K5 and K14 expression in the adult. In contrast, inner root sheath and matrix cells with early and sustained exposure to dermal papillae show little or no K14/K5 expression in the adult. These patterns of expression can be maintained even when cells are taken out of their natural environment and placed into tissue culture medium. Matrix cells seem to be the least differentiated cells of the hair follicle. These cells further differentiate into cortex and medulla cells, expressing high levels of hair-specific keratins (Heid et al. 1986; Lynch et al. 1986), and inner root sheath cells, expressing an unusual set of keratin-like proteins, referred to in the diagram as 'specific IRS keratins' (Stark et al. 1987). The expression of hair-specific keratins is a late event in hair follicle development and occurs well after the major events of morphogenesis. 


\section{Do hair-specific keratins play a role in hair follicle morphogenesis?}

The expression of a set of keratins unique to hair follicles has led to the speculation that these keratins may play a role in tailoring the cytoskeletal architecture of hair cells to suit their particular structural needs. If this is the case, then it might be expected that expression of hair-specific keratins should either precede or coincide with morphogenesis of the hair follicle. However, our findings clearly indicate that expression of high levels of hair-specific keratin mRNAs and their proteins is a relatively late biochemical consequence of follicle development, occurring between 2 and 5 days after birth. In striking contrast, hair follicle morphogenesis begins in mid-development, with hair germs evident as early as 15-16 days of gestation and fetal hair structures present as early as 19 days of gestation. By the time hair-specific keratin expression is greatly elevated in the follicle 15 days postbirth), the morphological development of the outer root sheath, inner root sheath, cortex, and medulla is largely complete, and the overall density of hair follicles is near maximal. Collectively, our results indicate that hair keratin expression seems to be a consequence of follicle differentiation, and does not appear to play a major role in dictating the morphology or organization of the cells within the follicle structure.

Although hair-specific keratin expression may not be involved in morphogenesis of follicles, it could contribute to the overall properties of the resulting hairs, e.g., their strength, rigidity, and flexibility. It is also intriguing to note that the time at which abundant hairspecific keratin mRNA expression occurs is also a time at which the size of the hair follicle becomes established and the rate of mitosis slows in the matrix cells. In this regard, the analogy between hair-specific keratin mRNA expression and terminal differentiation-specific keratin mRNA expression is striking. Both sets of keratin mRNAs are produced in the first suprabasal layer of cells removed from their mesenchymal support, and both sets of keratin mRNAs seem to be produced in cells that may concomitantly lose their potential to divide. Hence, it seems possible that these unusual sets of keratins may not simply be bystanders of differentiation but may also be intimately involved in some regulatory step of their differentiative programs.

\section{Experimental procedures}

\section{Animals}

Female rats (Sprague-Dawley) at 13-21 days of pregnancy were obtained from SASCO (Omaha, Nebraska). Upon arrival, rats were sacrificed, and their embryos were isolated. The length of pregnancy was estimated by the vendor according to the time postappearance of a vaginal plug $(t=0)$, and was verified when we examined the relative sizes of the embryos. Some embryos from each stage of development were fixed in either Carnoy's fixative (for immunohistochemistry) or $4 \%$ paraformaldehyde (for immunohistochemistry and in situ hybridizations). Back skins from other embryos of the same litters were dissected and used for protein and mRNA extractions. For rats at $t=7,9,15$, and 30 days postbirth, and for adult rats, back skin was shaved and either fixed in $4 \%$ paraformaldehyde or subjected to protein and mRNA extractions.

\section{RNA extraction}

The procedure used for RNA extraction was essentially as described by Maniatis et al. (1982), with some minor modifications. Back skin was removed from embryos and rats of all ages (14-20 days of gestation, newborn, 2-30 days postbirth, and adult), and the tissues were snap-frozen in liquid nitrogen. The frozen tissues were pulverized under liquid nitrogen with the aid of a mortar and pestle, and the powdered tissues were then placed in a solution of $4 \mathrm{M}$ guanidinium isothiocyanate, $14 \%$ $\beta$-mercaptoethanol, $5 \mathrm{~mm}$ EDTA, and $0.1 \mathrm{M}$ Tris- $\mathrm{HCl}$ (pH 7.5). The samples were then subjected to centrifugation at $4000 \mathrm{~g}$ for $10 \mathrm{~min}$ at $4^{\circ} \mathrm{C}$. The pellets were saved for keratin extractions (see below), and the supernatants were layered onto $\mathrm{CsCl}$ cushions and subjected to ultracentrifugation at $200,000 \mathrm{~g}$ at room temperature for $20 \mathrm{hr}$. The supernatants were saved for keratin extractions (see below) and the RNA pellets were resuspended in the guanidinium solution described above. RNAs were then precipitated with 0.75 volumes of ethanol $\left(-20^{\circ} \mathrm{C}\right)$. After centrifugation, final pellets were resuspended in $0.5 \%$ SDS solution and either poly(A)-selected via oligo (dT)-cellulose chromatography or stored at $-70^{\circ} \mathrm{C}$ until use.

\section{Keratin extractions}

1. From samples used for RNA preparation. The pellets from the low-speed centrifugation step were combined with the supernatants from the high-speed centrifugation step (see above) and dialyzed against an ice-cold solution of $0.6 \mathrm{M} \mathrm{KCl}, 1 \%$ Triton X-100, $0.1 \mathrm{M}$ Tris- $\mathrm{HCl}(\mathrm{pH} 7.4)$, and $0.3 \mathrm{mg} / \mathrm{ml}$ phenylmethyl sulfonylfluoride (PMSF). The dialysate was then subjected to sonication $\left(4 \times 15 \mathrm{sec}, 4^{\circ} \mathrm{C}\right)$, followed by centrifugation $(10,000 \mathrm{~g})$ for $20 \mathrm{~min}$. Pellets were resuspended by sonication and washed three times in the $\mathrm{KCl}$ solution. Final pellets were resuspended in $8 \mathrm{M}$ urea and $10 \% \beta$-mercaptoethanol $/ \mathrm{Wu}$ et al. 1982).

2. From back skin and hair shafts. Whole back skin of embryos, shaved back skin of rats, or clipped rat hairs were placed in the $\mathrm{KCl}$ solution as described above and subjected to sonication as described by Wu et al. (1982). Following centrifugation $(10,000 \mathrm{~g})$ for $20 \mathrm{~min}$ at $4^{\circ} \mathrm{C}$, the pellet was resuspended in the same solution and the sonication and centrifugation procedures were repeated three times. The final pellets were dissolved in $8.5 \mathrm{M}$ urea and $10 \% \quad \beta$-mercaptoethanol $(\mathrm{pH} 9.5)$ to solubilize both hair and epidermal keratins (Lynch et al. 1986).

\section{Gel electrophoresis}

Keratin samples were subjected to either $(1)$ one-dimensional SDS-polyacrylamide gel electrophoresis (Laemmli 1970) or (2) two-dimensional gel electrophoresis, with the first dimension as nonequilibrium $\mathrm{pH}$ (NEPHGE) gel electrophoresis and the second dimension as SDS-polyacrylamide gel electrophoresis (O'Farrell et al. 1977). To visualize the keratins, gels were either stained with Coomassie blue or silver or subjected to immunoblot analyses. 


\section{Immunoblot analyses}

Keratins resolved by SDS-polyacrylamide gel electrophoresis were transferred to nitrocellulose by electroblotting. Blots were subjected to immunoanalyses as described by Towbin et al. (1979). Antisera used for primary hybridization were rabbit polyclonal anti-type $I(1: 50)$ and anti-type II $(1: 50)$ keratin (Fuchs and Marchuk 1983), and a mixture of rabbit polyclonal antisera made against cultured human epidermal keratins expressed in vitamin A-containing medium (Fuchs and Marchuk 1983; Kim et al. 1984).

\section{Immunohistochemistry}

Fixed embryos or back skin were embedded in paraffin, sectioned $(5 \mu \mathrm{m})$, and hydrated for staining. Sections were treated for $30 \mathrm{~min}$ at room temperature with a solution of $2 \%$ bovine serum albumin in phosphate-buffered saline (BSA-PBS). The solution was then replaced with fresh BSA-PBS containing a $1: 200$ dilution of a monospecific rabbit polyclonal antiserum against a synthetic 15-mer coding for the carboxyl terminus of human K14 (Stoler et al. 1988). This antiserum also cross-reacts strongly with $\mathrm{K} 14$ of rat. Following a $1-\mathrm{hr}$ incubation at room temperature, sections were washed $3 \times$ in PBS (10 min each) and then treated with a gold-conjugated goat anti-rabbit antiserum (15-nm gold particles, Janssen Life Science Products, Piscataway, New Jersey). After an overnight incubation at room temperature, sections were washed $6 \times$ in PBS (10 min each), fixed for $15 \mathrm{~min}$ in PBS containing $2 \%$ glutaraldehyde, and washed three times in PBS (10 min each) followed by $3 \times$ in glass-distilled water ( $10 \mathrm{~min}$ each). Sections were then placed in a single glass jar, along with negative control sections in which the primary antiserum was omitted, and positive control sections of previously characterized human epidermis (Stoler et al. 1988). Sections were then subjected to silver enhancement (IntenSE, Janssen Life Science Products), according to the manufacturer's instructions. Enhancement was stopped for all sections when the control human epidermal sections showed the familiar pattern of basal-preferred K14 staining.

\section{In situ hybridization}

Embryos or back skins were fixed in $4 \%$ paraformaldehyde for $6 \mathrm{hr}$ at room temperature. Fixed samples were embedded in paraffin and sectioned $(5 \mu \mathrm{m})$, and sections were subjected to in situ hybridizations according to the procedures of Cox et al. (1984), as described previously (Tyner and Fuchs 1986; Stoler et al. 1988).

cRNA probes labeled with ${ }^{35} \mathrm{~S}$-labeled-UTP were generated from the following plasmids: (1) 3 sp, a derivative of plasmid pSP65 (Promega Biotec) containing a 1080-bp BstII-StuI fragment encompassing nucleotide residues $170-1250$ of KB-2, a 1410-bp cDNA encoding human keratin K14 (Hanukoglu and Fuchs 1982; Stoler et al. 1988). The insert was cloned into the HincII site of pSP65. Antisense cRNAs were generated by linearizing the plasmid with HindIII and using SP6 RNA polymerase (Promega Biotec) in the presence of ${ }^{35}$ S-labeled-UTP and unlabeled ribonucleotides. (2) pKSV15, a derivative of plasmid pKS-M13- (Stratagene) containing an 875-bp BgII-DraII fragment encompassing $840 \mathrm{bp}$ of coding and $35 \mathrm{bp}$ of $3^{\prime}$ noncoding sequence of cDNA V15, encoding a sheep wool type I keratin (generously provided by Dr. Kevin Ward). The insert was cloned into the SmaI site of pKS-M13- ${ }^{-}$. Antisense cRNAs were generated by linearizing the plasmid with DraII, and using T7 RNA polymerase (Stratagene) in the presence of ${ }^{35} \mathrm{~S}$-labeled-UTP and unlabeled ribonucleotides. Sense (control) cRNAs were generated by linearizing the plasmid with SpeI, and using T3 RNA polymerase (Stratagene) in the presence of ${ }^{35}$ S-labeled-UTP and unlabeled ribonucleotides.

\section{Northern blot analysis}

mRNAs were isolated as described above and subjected to Northern blot analyses as described by Thomas (1980). Singlestranded cDNA probes labeled with ${ }^{32}$ PdCTP were prepared from the following plasmids: (1) pKSV15, as described above, using a T7 primer (Stratagene) and Klenow fragment of Escherichia coli DNA polymerase (Boehringer-Mannheim). (2) pGEMK5, a 1354-bp FnuDII-XbaI fragment encompassing a large portion of the human K5-coding region of plasmid KA-62 (nucleotide residues 254-1608) and subcloned in the $5^{\prime}$ to $3^{\prime}$ direction into the SmaI-XbaI site of plasmid pGEM2 (Promega Biotec) (Lersch and Fuchs 1988). Antisense probe was prepared by linearizing pGEMK5 with HindIII and using a T7 primer and Klenow fragment in the presence of $\left[{ }^{32} \mathrm{P}\right]$-dCTP and unlabeled deoxyribonucleotides.

\section{Acknowledgments}

We would like to extend a very special thank you to Dr. Kevin Ward (CSIRO, Sydney, Australia) for his generous gift of the wool type I keratin cDNA (V15), and to Dr. George Rogers (Department of Biochemistry, The University of Adelaide, Adelaide, South Australia) for his valuable discussions. We thank Dr. Andrea Stoler for her helpful advice on the techniques of in situ hybridization, and Linda Foster for her expert technical assistance in preparing histological sections. We are also grateful to Mr. Philip Galiga and Mr. David Rosenzweig for their artful assembly of the figures. Finally, a special thank you goes to Dr. Aron Moscona (The University of Chicago) for his critical reading of the manuscript and for his enthusiastic encouragement throughout the course of these studies. This work was supported by a grant from the National Institutes of Health (AR31737). E.F. is the recipient of a Presidential Young Investigator Award from the National Science Foundation. R.K. is a predoctoral trainee funded by a grant from the Levin Fund.

\section{References}

Banks-Schlegel, S.P. 1982. Keratin alterations during embryonic epidermal differentiation: A presage of adult epidermal maturation. J. Cell Biol. 93: 551-559.

Billingham, R.E. and W.K. Silvers 1968. Dermo-epidermal interactions and epithelial specificity. Epithelial-mesenchymal interactions (ed. R. Fleischmajer and R.E. Billingham), pp 252. Williams and Wilkins Co., Baltimore.

Breathnach, A.S. and J. Smith 1968. Fine structure of the early hair germ and dermal papilla in the human foetus. I. Anat. 102: $511-526$.

Cohen, J. 1961. The tranplantation of individual rat and guineapig whisker papillae. J. Embryol. Exp. Morphol. 9: 117-127.

Cox, K.H., D.V. DeLeon, L.M. Angerer, and R.C. Angerer. 1984. Detection of mRNAs in sea urchin embryos by in situ hybridization using asymmetric RNA probes. Dev. Biol. 101: 485-502.

Crewther, W.G., L.M. Dowling, D.A.D. Parry, and P.M. Steinert. 1983. The structure of intermediate filaments. Int. J. Biol. Macromol. 5: 267-282.

Dale, B.A., K.A. Holbrook, J.R. Kinball, M. Hoff, and T.-T. Sun. 1985. Expression of epidermal keratins and filaggrin during human fetal skin development. I. Cell Biol. 101: 12571269. 
Davidson, P. and M.H. Hardy. 1952. The development of mouse vibrissae in vivo and in vitro. J. Anat. Physiol. 86: 342-356.

Dhouailly, D. 1977. Regional specification of cutaneous appendages in mammals. Wilhelm Roux's Arch. Dev. Biol. 181: $3-10$.

Doran, T.I., A. Vidrich, and T.-T. Sun. 1980. Intrinsic and extrinsic regulation of the differentiation of skin, corneal and esophageal epithelial cells. Cell 22: 17-25.

Dowling, L.M., W.G. Crewther, and A.S. Inglis. 1986. The primary structure of component $8 \mathrm{c}-1$, a subunit protein of intermediate filaments in wool keratin. Biochem. J. 236: 695703.

Eichner, R., P. Bonitz, and T.-T. Sun. 1984. Classification of epidermal keratins according to their immunoreactivity, isoelectric point, and mode of expression. I. Cell Biol. 98: $1388-1396$.

French, P.W. and D.R. Hewish. 1986. Localization of low-sulfur keratin proteins in the wool follicle using monoclonal antibodies. J. Cell Biol. 102: 1412-1418.

Fuchs, E. and H. Green. 1980. Changes in keratin gene expression during terminal differentiation of the keratinocyte. Cell 19: $1033-1042$.

-1981. Regulation of terminal differentiation of cultured human keratinocytes by vitamin A. Cell 25: 617-625.

Fuchs, E. and D. Marchuk. 1983. Type I and type II keratins have evolved from lower eukaryotes to form the epidermal intermediate filaments in mammalian skin. Proc. Natl. Acad. Sci. 80: 5857-5861.

Fuchs, E., A.L. Tyner, G.J. Giudice, D. Marchuk, A. RayChaudhury, and M. Rosenberg. 1987. The human keratin genes and their differential expression. Curr. Top. Dev. Biol. 22: 5-34.

Hanukoglu, I. and E. Fuchs. 1982. The cDNA sequence of a human epidermal keratin: divergence of sequence but conservation of structure among intermediate filament proteins. Cell 31: 243-252.

1983. The cDNA sequence of a type II cytoskeletal keratin reveals constant and variable structural domains among keratins. Cell 33: 915-924.

Hashimoto, K. 1970. The ultrastructure of the skin of human embryos. IX. Formation of the hair cone and intraepidermal hair canal. Arch. Klin. Exp. Dermatol. 238: 333-345.

Heid, H.W., I. Moll, and W.W. Franke. 1988a. Patterns of expression of trichocytic and epithelial cytokeratins in mammalian tissue. I. Human and bovine hair follicle. Differentiation 37: 137-157.

- 1988b. Patterns of expression of trichocytic and epithelial cytokeratins in mammalian tissue. II. Concomitant and mutually exclusive synthesis of trichocytic and epithelial cytokeratins in diverse human and bovine tissue (hair follicle, nail bed and matrix, lingual papilla, thymic reticulum|. Differentiation 37: 215-230.

Heid, H.W., E. Werner, and W.W. Franke. 1986. The complement of native alpha-keratin polypeptides of hair-forming cells: a subset of eight polypeptides that differ from epithelial cytokeratins. Differentiation 32: 101-119.

Hennings, H.D., M.C. Cheng, P. Steinert, K. Holbrook, and S.H. Yuspa. 1980. Calcium regulation of growth and differentiation of mouse epidermal cells in culture. Cell 19: 245-254.

Hewish, D.R. and R.C. Marshall. 1982. In vitro growth and differentiation of epithelial cells derived from post-embryonic hair follicles. Aust. I. Biol. Sci. 35: 103-109.

Ibrahim, L. and E.A. Wright. 1982. A quantitative study of hair growth using mouse and rat vibrissal follicles. I. Embryol. Exp. Morph. 72: 209-224.

Ito, M., T. Tazawa, N. Shimizu, K. Katsuumi, Y. Sato, and K. Hashimoto. 1986. Cell differentiation in human anlagen hair and hair follicles studied with anti-hair keratin monoclonal antibodies. J. Invest. Dermatol. 86: 563-569.

Jackson, B.W., C. Grund, S. Winter, W.W. Franke, and K. Illmensee. 1981. Formation of cytoskeletal elements during mouse embryogenesis. II. Epithelial differentiation and intermediate-size filaments in early postimplantation embryos. Differentiation 20: 203-216.

Jacobson, C.M. 1966. A comparative study of the mechanisms by which $\mathbf{x}$-irradiation and genetic mutation cause loss of vibrissae in embryo mice. J. Embryol. Exp. Morph. 16: 369179.

Jahoda, C.A.B., K.A. Horne, and R.F. Oliver. 1984. Induction of hair growth by implantation of cultured dermal papilla cells. Nature 311: 560-562.

Jorcano, J.L., J.K. Franz, and W.W. Franke. 1984a. Amino acid sequence diversity between bovine epidermal cytokeratin polypeptides of the basic (type II) subfamily as determined from cDNA clones. Differentiation 28: 155-163.

Jorcano, J.L., M. Reiger, J.K. Franz, D.L. Schiller, R. Moll, and W.W. Franke. 1984b. Identification of two types of keratin polypeptides within the acidic cytokeratin subfamily I. $J$. Mol. Biol. 179: 357-281.

Kim, K.H., F. Schwartz, and E. Fuchs. 1984. Differences in keratin synthesis between normal epithelial cells and squamous cell carcinomas are mediated by vitamin A. Proc. Natl. Acad. Sci. 81: 4280-4284.

Kollar, E.J. 1970. The induction of hair follicles by embryonic dermal papillae. I. Invest. Derm. 55: 374-378.

Kopan, R., G. Traska, and E. Fuchs. 1987. Retinoids as important regulators of terminal differentiation: examining keratin expression in individual epidermal cells at various stages of keratinization. J. Cell Biol. 105: 427-440.

Laemmli, U.K. 1970. Cleavage of structural proteins during the assembly of the head of bacteriophage T4. Nature 227: 680685.

Lersch, R. and E. Fuchs. 1988. Sequence and expression of a type II keratin, K5, in human epidermal cells. Mol. Cell. Biol. 8: 486-493.

Lynch, M.H., W.M. O'Guin, C. Hardy, L. Mak, and T.-T. Sun. 1986. Acidic and basic hair/nail ('hard') keratins: their colocalization in upper cortical and cuticle cells of the human hair follicle and their relationship to 'soft' keratins. J. Cell Biol. 103: 2593-2606.

Maniatis, T., E.F. Fritsch, and J. Sambrook. 1982. Molecular cloning: a laboratory manual. Cold Spring Harbor Laboratory, Cold Spring Harbor, New York.

Marshall, R.C. and J.M. Gillespie. 1977. The keratin proteins of wool, horn and hoof from sheep. Aust. J. Biol. Sci. 30: 389400.

Meyer, W. and S. Gorgen. 1986. Development of hair coat and skin glands in fetal porcine integument. I. Anat. 144: 201220.

Moll, R., I. Moll, and W. Wiest. 1982a. Changes in the pattern of cytokeratin polypeptides in epidermis and hair follicles during skin development in human fetuses. Differentiation 23: $170-178$.

Moll, R., W. Franke, D. Schiller, B. Geiger, and R. Krepler. 1982b. The catalog of human cytokeratins: patterns of expression in normal epithelia, tumors and cultured cells. Cell 31: $11-24$.

Montagna, W. and P.F. Parakkal. 1974. The structure and function of skin. 3rd ed. Academic Press, New York, pp. 1-433.

Moscona, A.A. and B.B. Garber. 1968. Reconstruction of skin from single cells and integumental differentiation in cell aggregates. In Epithelial-mesenchymal interactions. (ed. R.E. 
Billingham and R.W. Fleischmajer) pp. 230-243. Williams and Wilkins Co., Baltimore.

Nagle, R.B., W. Bocker, J.R. Davis, H.W. Heid, M. Kaufmann, D. Lucas, and E.D. Jarasch. 1986. Characterization of breast carcinomas by two monoclonal antibodies distinguishing myoepithelial from luminal epithelial cells. $/$. Histochem. 34: $869-888$.

Nelson, W. and T.-T. Sun. 1983. The 50- and 58-kdalton keratin classes as molecular markers for stratified squamous epithelia: cell culture studies. /. Cell Biol. 97: 244-251.

O'Farrell, P.Z., H.M. Goodman, and P.H. O'Farrell. 1977. High resolution two-dimensional electrophoresis of basic as well as acidic proteins. Cell 12: 1133-1142.

Oliver, R.F. 1966a. Whisker growth after removal of the dermal papilla and lengths of follicle in the hooded rat. I. Embryol. Exp. Morphol. 15: 331-347.

. 1966b. Histological studies of whisker regeneration in the hooded rat. J. Embryol. Exp. Morphol. 16: 231-244.

1970. The induction of hair follicle formation in the adult hooded rat by vibrissa dermal papillae. $/$. Embryol. Exp. Morphol. 23: 219-236.

Pinkus, F. 1910. The development of the integument. In Manual of human embryology, (ed. Keibel and Mall), vol I, pp. 243-291. Lippincott, Philadelphia.

1958. Embryology of hair. In The biology of hair growth (ed. W. Montagna and R.A. Ellis) pp. 1-23, Academic Press, New York.

Pisansarakit, P. and G.P.M. Moore. 1986. Induction of hair follicles in mouse skin by rat vibrissa dermal papillae. $J$. Embryol. Exp. Morph. 94: 113-119.

Rheinwald, J.G. and H. Green. 1975. Serial cultivation of strains of human epidermal keratinocytes: The formation of keratinizing colonies from single cells. Cell 6: $331-343$.

Rogers, G., N. Martinet, P. Steinert, P. Wynn, D. Roop, A. Kilkenny, D. Morgan, and S.H. Yuspa. 1987. Cultivation of murine hair follicles as organoids in a collagen matrix. I. Invest. Dermatol. 89: 369-379.

Stark, H.-J., D. Breitkreutz, A. Limat, P. Bowden and N.E. Fusenig. 1987. Keratins of the human hair follicle: hyperproliferative keratins consistently expressed in outer root sheath cells in vivo and in vitro. Differentiation 35: 236-248.

Steinert, P.M., P.Y. Dyer, and G.E. Rogers. 1971. The isolation of non-keratin protein filaments from inner root sheath cells of the hair follicle. I. Invest. Dermatol. 56: 49-54.

Steinert, P.M., R.H. Rice, D.R. Roop, B.L. Trus, and A.C. Steven. 1983. Complete amino acid sequence of a mouse epidermal keratin subunit and implications for the structure of intermediate filaments. Nature 302: 794-800.

Steinert, P., D. Parry, E. Racoosin, W. Idler, A. Steven, B. Trus, and D. Roop. 1984. The complete cDNA and deduced amino acid sequence of a type II mouse epidermal keratin of 60,000 Da: Analysis of sequence differences between type I and type II keratins. Proc. Natl. Acad Sci. 81: 5709-5713.

Steinert, P.M., A.C. Steven, and D.R. Roop. 1985. The molecular biology of intermediate filaments. Cell 42: 411-419.

Stoler, A., R. Kopan, M. Duvic, and E. Fuchs. 1988. The use of monospecific antibodies and cRNA probes reveals abnormal pathways of differentiation in human epidermal diseases. $J$. Cell Biol. 107: 427-446.

Sun, T.-T. and H. Green. 1978. Keratin filaments in cultured human epidermal cells. J. Biol. Chem. 253: 2053-2060.

Sun, T.-T., R. Eichner, A. Schermer, D. Cooper, W.G. Nelson, and R.A. Weiss. 1984. Classification, expression, and possible mechanisms of evolution of mammalian epithelial keratins: a unifying model. In The cancer cell. Vol. 1. The transformed phenotype. (ed. A. Levine, W. Topp, G. van de
Woude, and J.D. Watson), pp. 169-176. Cold Spring Harbor Laboratory, Cold Spring Harbor, New York.

Thomas, P. 1980. Hybridization of denatured RNA and small DNA fragments transferred to nitrocellulose. Proc. Natl, Acad. Sci. 77: 5201-5205.

Towbin, H., T. Staehelin, and J. Gordon. 1979. Electrophoretic transfer of proteins from polyacrylamide gels onto nitrocellulose sheets: Procedure and some applications. Proc. Natl. Acad. Sci. 81: 4683-4687.

Tyner, A.L. and E. Fuchs. 1986. Evidence for posttranscriptional regulation of the keratins expressed during hyperproliferation and malignant transformation in human epidermis. $J$. Cell Biol. 103: 1945-1955.

Watt, F.M., D.L. Mattey, and D.R. Garrod. 1984. Calcium-induced reorganization of desmosomal components in cultured human keratinocytes. J. Cell Biol. 99: 2211-2215.

Weiss, R.A., R. Eichner, and T.-T. Sun. 1984. Monoclonal antibody analysis of keratin expression in epidermal diseases: $\mathrm{A}$ 48- and 56-kdalton keratin as molecular markers for hyperproliferative keratinocytes. I. Cell Biol. 98: 1397-1406.

Wessels, N.K. and Roessner, K.D. 1965. Nonproliferation in dermal condensation of mouse vibrissae and pelage hairs. Dev. Biol. 12: 419-433.

Wu, Y.-J., L.M. Parker, N.E. Binder, M.A. Beckett, J.H. Sinard, C.T. Griffiths, and J.G. Rheinwald. 1982. The mesothelial keratins: A new family of cytoskeleton proteins identified in cultured mesothelial cells and nonkeratinizing epithelia. Cell 31: 693-703. 


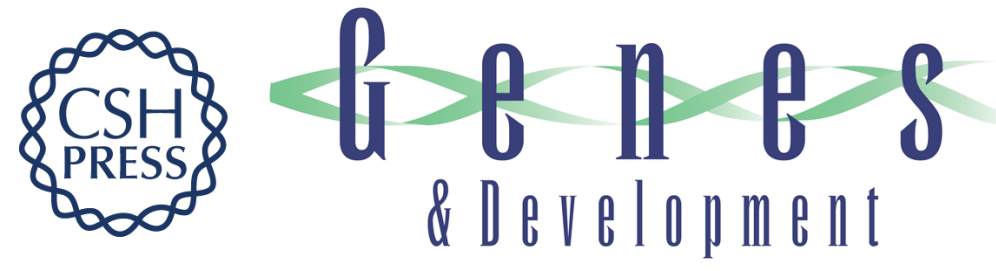

\section{A new look into an old problem: keratins as tools to investigate determination, morphogenesis, and differentiation in skin.}

R Kopan and E Fuchs

Genes Dev. 1989, 3:

Access the most recent version at doi:10.1101/gad.3.1.1

References

License

Email Alerting

Service
This article cites 62 articles, 18 of which can be accessed free at:

http://genesdev.cshlp.org/content/3/1/1.full.html\#ref-list-1

Receive free email alerts when new articles cite this article - sign up in the box at the top right corner of the article or click here.

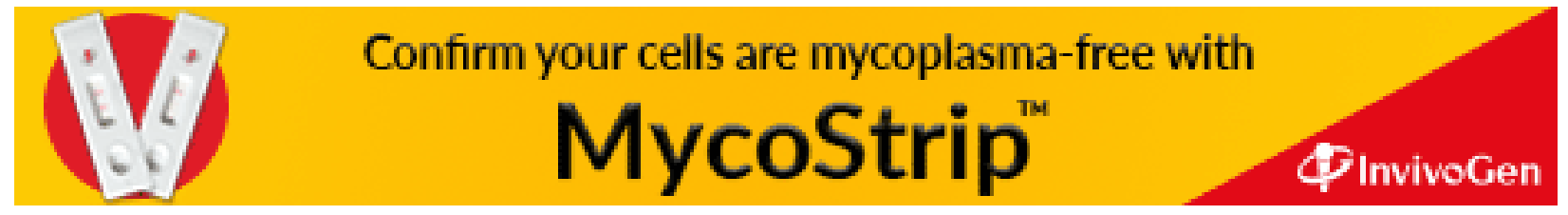

